Chirurgia (2019) 114: 512-517

No. 4, July - August

Copyright@ Celsius

http://dx.doi.org/10.21614/chirurgia.114.4.514

\title{
Male Breast Huge Malignant Phyllodes
}

\author{
Omar Hamdy ${ }^{1}$, Gehad A Saleh ${ }^{2}$, Sara Raafat ${ }^{3}$, Abdelhadi M Shebl ${ }^{3}$ and Adel Denewer ${ }^{1}$ \\ ${ }^{1}$ Surgical Oncology Unit, Oncology Center Mansoura University (OCMU), Mansoura, Egypt \\ ${ }^{2}$ Radiology Department, Faculty of Medicine, Mansoura University, Mansoura, Egypt \\ ${ }^{3}$ Pathology Department, Faculty of Medicine, Mansoura University, Mansoura, Egypt
}

Corresponding author:

Omar Hamdy, MD

Surgical Oncology Unit

Oncology Center Mansoura

University (OCMU), Mansoura, Egypt

E-mail: marhamdy87@gmail.com
Received: 17.03 .2018 Accepted: 20.05 .2018

\section{Rezumat}

\section{Tumoră Phyllodes gigantă, malignă, la un bărbat}

Introducere: Tumorile Phyllodes sunt tumori mamare rare. Tratamentul de elecție este excizia locală largă, cu margini de rezecție de $1 \mathrm{~cm}$ în cazurile benigne. În cazul pacienților bărbați au fost identificate trei tipuri patologice: benign, borderline şi malign. Prezentare de caz: Pacient de 73 de ani, cu o tumefacție masivă la sânul stâng, cuprinsă între claviculă şi regiunea hipocondrului stâng. Puncția biopsie cu an fin a relevat o tumoră Phyllodes malignă. Investigația $\mathrm{CT}$ cu substanță de contrast a relevat o masă tumorală în peretele stâng anterolateral al toracelui cu dimensiunea de $22 \times 25 \times 26 \mathrm{~cm}$. A fost efectuată mastectomie simplă cu rezecție în bloc. Rezultatul histopatologic a stabilit diagnosticul de tumoră Phyllodes malignă cu grad ridicat. Imunohistochimia a relevat vimentin pozitiv difuz, CD10 şi CK negativ în celulele neoplazice. Pacientul nu s-a prezentat pentru urmărire timp de trei luni. Când s'a prezentat din nou la medic avea recidivă locală şi metastază pulmonară bilaterală. Pacientul a fost supus unei intervenții chirurgicale paliative. După cea de-a doua intervenție chirurgicală, pacientul a fost pregătit pentru chimioterapie paliativă, dar a decedat o lună mai târziu, acasă.

Discuții şi concluzii: Au fost puține cazuri de tumori Phyllodes raportate la bărbați. Patologic, tumorile Phyllodes pot fi de trei tipuri: benigne, borderline şi maligne în funcție de activitatea mitotică, natura marginilor de rezecție, creşterea stromală, celularitate şi atipie. Tumorile Phyllodes maligne tind să se extindă hematologic către plămâni, apoi către oase. Tumorile Phyllodes tind să recidiveze chiar după excizie completă, în special cele maligne, dar şi cele benigne. Tratamentul de elecție pentru tumorile Phyllodes este excizia locală largă - cu sau fără radio- 
terapie adjuvantă în leziunile maligne - fără rezultate dovedite ale chimioterapiei sau hormonoterapiei.

Cuvinte cheie: san, tumoră Phyllodes, leziune malignă

\begin{abstract}
Introduction: Phyllodes tumors are rare breast tumors. The best treatment is wide local excision with $1 \mathrm{~cm}$ safety margin unless metastatic. The three pathological types (benign, borderline and malignant were reported in men.

Case presentation: A 73year-old male with huge left breast swelling extending from the clavicle to the left hypochondriac region. Core needle biopsy suggested malignant phyllodes tumor. Postcontrast CT revealed a huge mass seen at the left anterolateral chest wall measuring about (22 x 25 x $26 \mathrm{~cm}$ ). Simple mastectomy was performed en bloc with the tumor. The microscopic examination led to the diagnosis of high grade malignant phyllodes. IHC showed diffuse positive vimentin, CD10 and negative CK in the neoplastic cells. The patient lost follow up for three months. Then he was presented with fungating local recurrence with bilateral metastatic pulmonary. The patient underwent palliative excision. After the second surgery, he was prepared for palliative chemoradiotherapy but the patient died one month later at home.

Discussion\& conclusions: Very few cases of phyllodes tumor were reported in men. Pathologically, phyllodes tumors are subdivided into three types: benign, borderline and malignant according to mitotic frequency, nature of margins, stromal growth, cellularity and atypia. Malignant phyllodes tumors tend to spread via hematological route mainly to the lung, then to the bone. Phyllodes tumors - even benign type- tend to recur even after complete excision with higher tendency for malignant cases. Wide local excision is the standard of care for phyllodes tumors - with or without adjuvant radiotherapy in malignant lesions- with no proved value for chemotherapy or hormonal therapy.
\end{abstract}

Key words: breast, phyllodes, malignant

\section{Introduction}

Phyllodes tumors are rare breast tumors, encountering for about $1 \%$ of all breast neoplasms with very rare incidence in men and few cases reported in literature, commonly preceded by gynecomastia. Best treatment is wide local excision with $1 \mathrm{~cm}$ safety margin unless metastatic. The three pathological types (benign, borderline and malignant) were reported in men (1).

\section{Case report}

Seventy three year-old male, farmer, married with six offspring, with neither relevant medical nor surgical history. He was presented to our center in August 2015 complaining from huge left breast swelling. Physical examination revealed accepted general condition with huge left breast swelling extending from the clavicle to the left hypochondrial region with normal right breast \& no suspicious axillary lymph nodes. Core needle biopsy revealed breast tissue showing infiltration by malignant spindle cell proliferation, necrotic areas were also seen. The primary diagnosis was malignant spindle cell proliferation most probably malignant phyllodes tumor. Post contrast CT (Fig. 1) revealed a huge heterogeneous mass 
Figure 1. Post contrast CT axial \& sagittal reformatted images $(A \& B)$ : Huge heterogeneously enhancing left anterolateral chest wall soft tissue mass with extensive central necrosis \& coarse calcification (arrow) is seen inseparable from left breast fibroglandular tissue as well as anterior chest wall muscles \& extending down to the left 5th anterior rib with no bony destruction. The mass is seen abutting left axillary artery (arrowhead) with preserved fat plane inbetween. No pathological axillary LNs could be detected
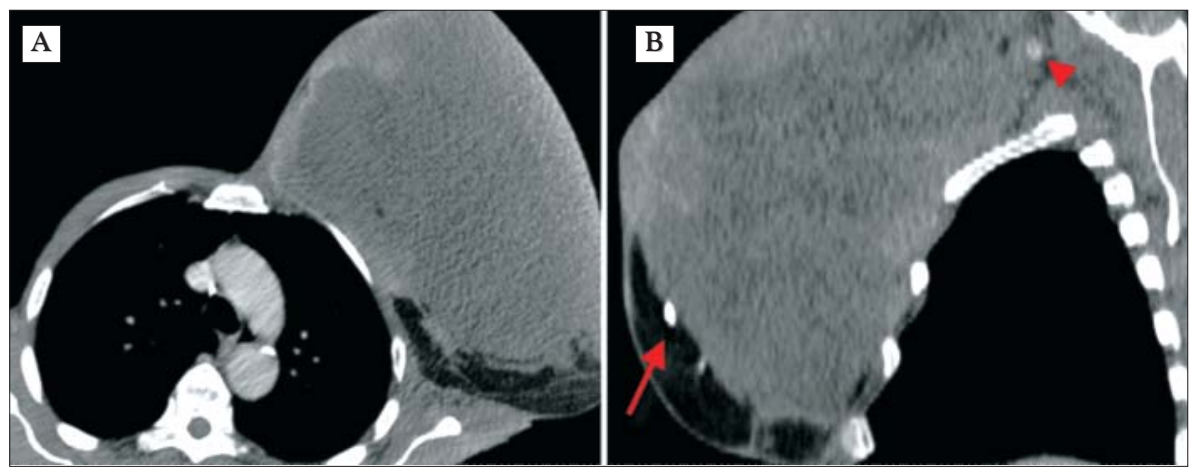

seen at the left anterolateral chest wall showing central necrosis with coarse calcifications inside measuring about $(22 \times 25 \times 26$ $\mathrm{cm})$. The mass was seen abutting the axillary artery with no encasement. Simple mastectomy was performed en bloc with the tumor. The gross specimen was received as a huge soft tissue mass measuring about 40x30x $15 \mathrm{~cm}$ covered by nipple, areola and skin ellipse measuring $10 \times 7 \mathrm{~cm}$. On dissection, it was firm in consistency and grayish white in colour with areas of extensive necrosis. Microscopic examination (Fig. 2) showed hypercellular malignant tumoral proliferation formed of

Figure 2. Microscopic examination of the first excision. (A): Hypercellular malignant tumoral proliferation formed of fascicles of malignant spindle cells. $\mathrm{H}$ \& E x200. (B): The spindle cells show high degree anaplasia and pleomorphism with frequent mitotic figures (> 10/10HPF). H \& Ex400.

(C): Malignant spindle cells with wide area of necrosis. $H$ \& E x100

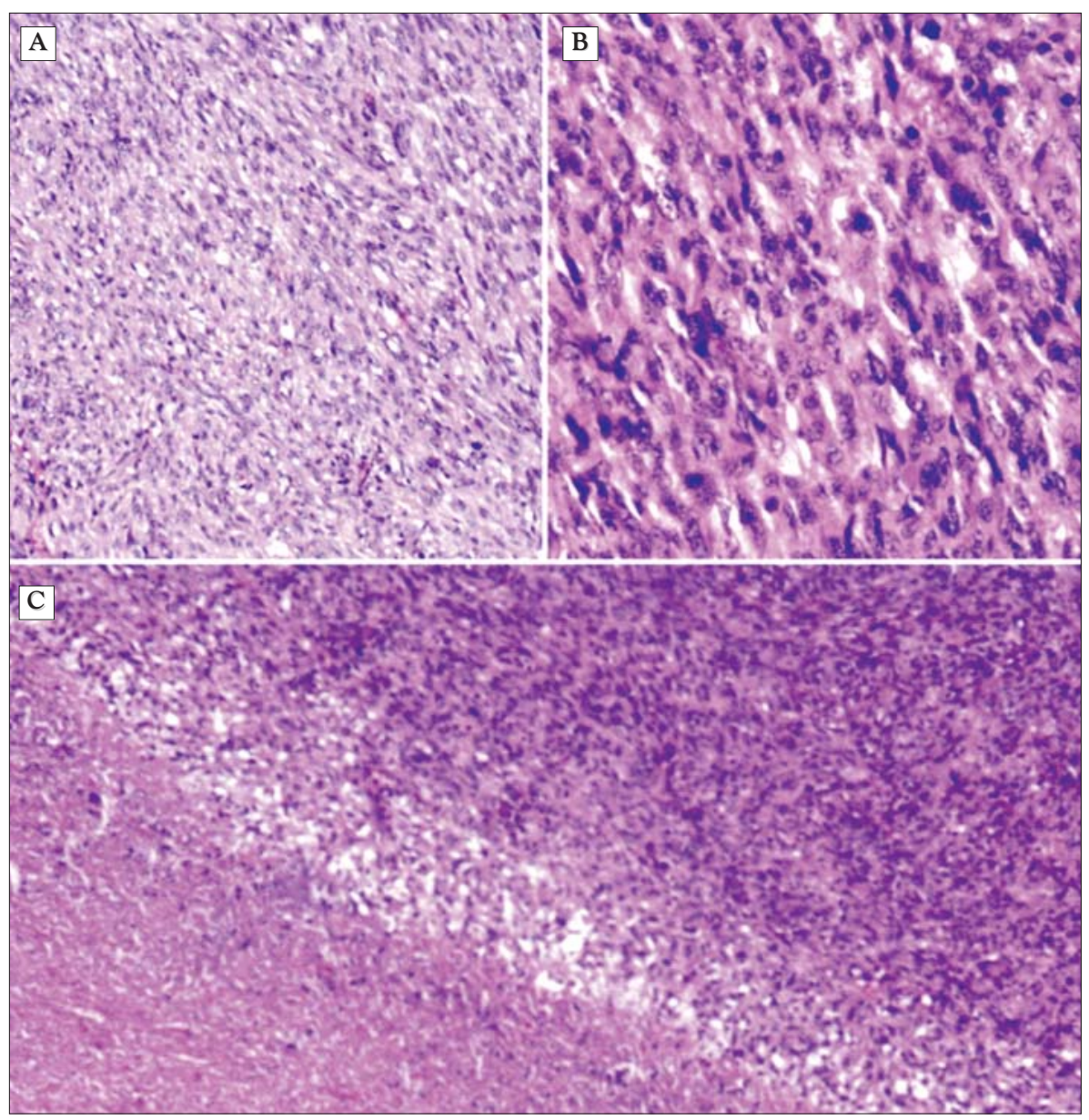


fascicles and bundles of malignant spindle cells exhibiting high degree anaplasia, pleomorphism and frequent mitotic figures (> 10/10 HPF) and wide necrotic areas. Immunohistochemistry (IHC) was done (Fig. 3) and it showed diffuse positive vimentin, CD10 and negative CK in the neoplastic cells. Sections prepared from skin were free from tumor tissue. The final diagnosis was high grade malignant phyllodes tumor. The patient was discharged on the following day. He was referred to clinical oncology department for consultation about radiotherapy. Yet, the patient lost follow up for three months. Three months later, the patient was presented with fungating local recurrence. Chest CT (Fig. 4) revealed few heterogeneously enhancing necrotic masses at the left antrolateral chest wall, the largest measured about $4.5 \times 6.5 \mathrm{~cm}$. Other enlarged masses were seen in the left axilla and the largest was $7.6 \times 16$ $\mathrm{cm}$. Few similar masses were seen encasing the left axillary artery for more than $180^{\circ}$ with no definite infiltration. The length of contacting segment measured about $3.7 \mathrm{~cm}$. Few variable sized bilateral metastatic pulmonary nodules were seen; the largest was seen in left upper lung lobe measuring about $2.2 \mathrm{~cm}$. The patient underwent palliative excision with microscopic examination and IHC showing recurrent high grade malignant phyllodes tumor. After the second surgery, he was prepared for palliative chemoradiotherapy with single agent Holoxane with $25 \%$ reduction and radiotherapy on palliative base 50 gy/25 sessions. The patient died one month later at home from a non-rivaled cause.

\section{Discussion}

Phyllodes tumors (previously named cystosarcoma phyllodes) are biphasic tumors

Figure 3. Immunohistochemical study of the first excision. (A): Diffuse positive CD10 in the neoplastic cells (immunoperoxidase-DAB x100). (B): Diffuse positive vimentin in the neoplastic cells (immuno-peroxidase-DAB x200). (C): Negative CK in the neoplastic cells (immunoperoxidase-DAB x100)

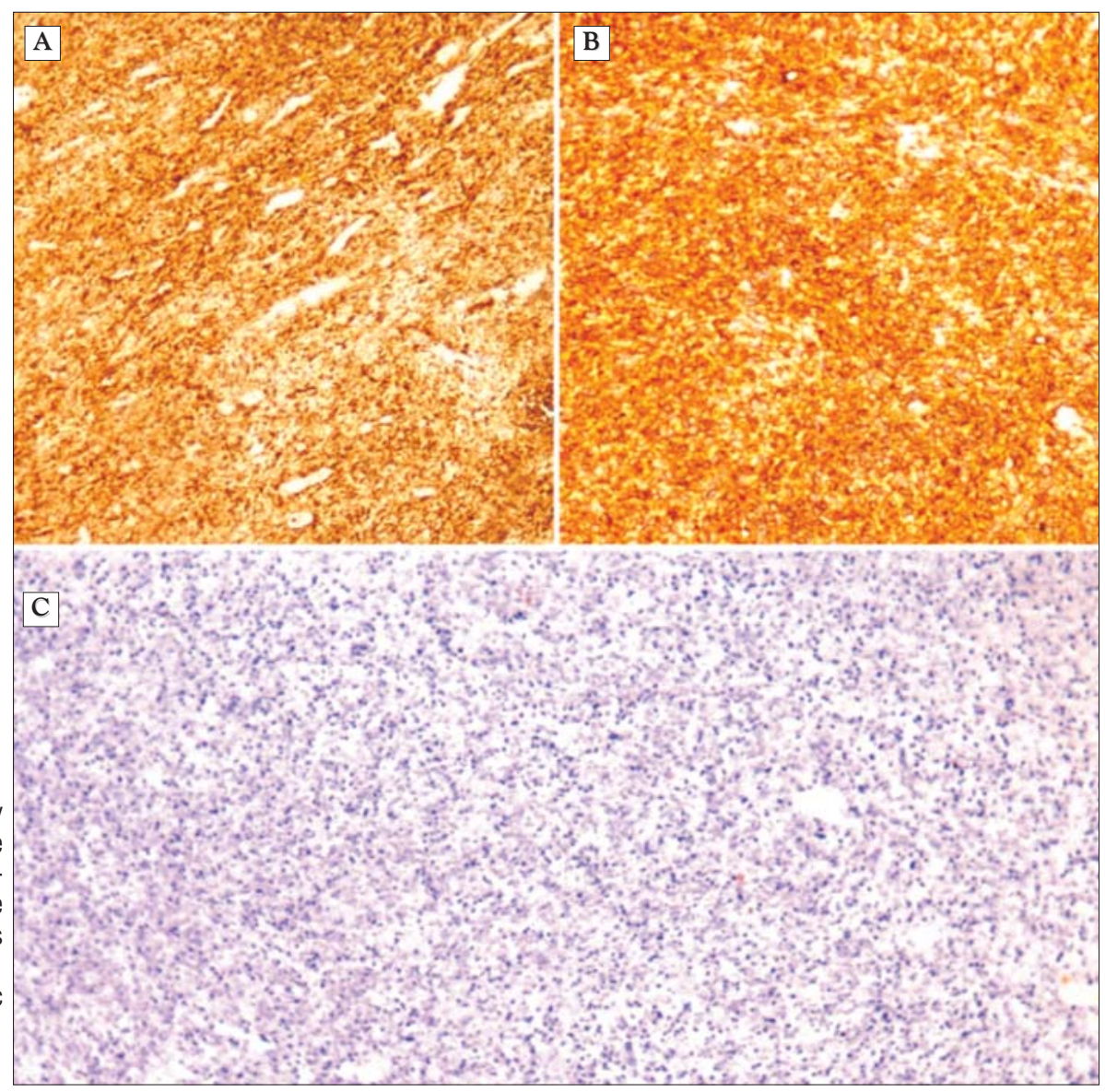


Figure 4. Post contrast CT axial mediastinal (A \& B), pulmonary window (C) \& sagittal reformatted images (D): Few heterogeneously enhancing necrotic masses over the left antero-lateral chest wall at the scar site, with fungating one (arrowhead) \& similar left axillary masses are seen encasing the left axillary artery with more than $180^{\circ}$ tumor contact (arrows). Intact underlying ribs. Few variable sized bilateral metastatic pulmonary nodules are detected, the largest measures $2.2 \mathrm{~cm}$ in diameter (arrow)
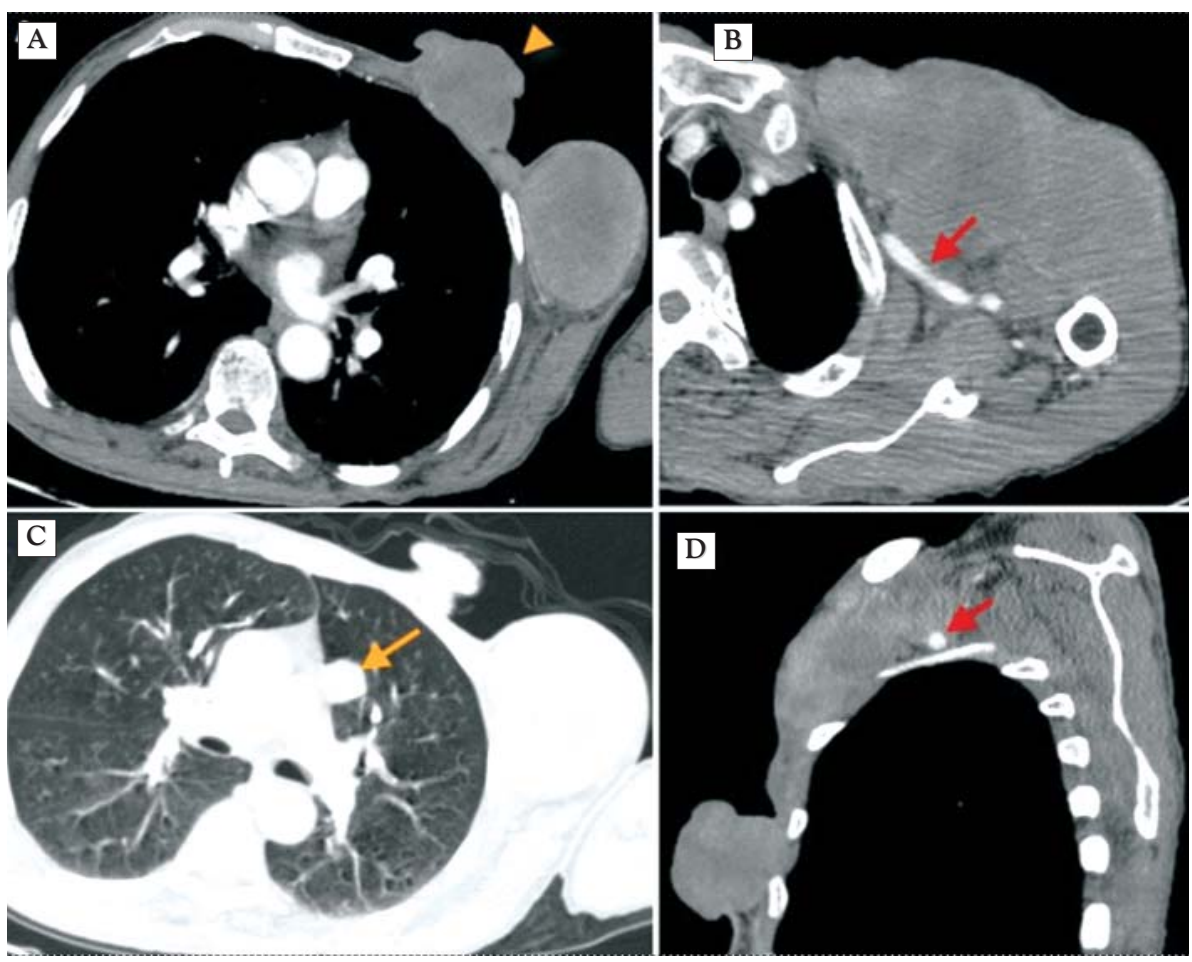

composed of both epithelial and stromal elements. They are pathologically classified into; benign, borderline and malignant. This classification is based on variable features such as degree of cellular pleomorphism, mitotic count, stromal overgrowth and margin type. The incidence in women is less than 1\% of all breast tumors and 2-3\% of fibroepithelial tumors. Very few cases were reported in men due to infrequent lobular development. The reported cases are mostly linked with preexisting gynecomastia. Phyllodes tumors were also reported in seminal vesicles \& prostate (1-5).

The incidence link with gynecomastia led to a proposal that development of male phyllodes may be preceded with lobular development in male breast due to hormonal imbalance between estrogen \& androgens $(3,6)$ Our patient was not obese (BMI: 21) with no relevant medical history. He was moderate smoker for 35 years.

The previously reported cases had a mean age of 53 years old while the tumor diameter ranged from 1-45 centimeters $(3,7)$. Our case can be considered one of the oldest cases as well as being one of the largest reported tumors.

On radiologic evaluation, phyllodes tumors appear in mammogram as well defined hyperdense oval polylobulated masses which may contain calcifications. At ultrasonography, they may present as a solid oval well circumscribed hypoechoic mass with parallel orientation, it may contain cystic areas. MRI may use cystic changes and wall irregularity as differentiating features between benign and malignant phyllodes. However, in general, radiological evaluation is not accurate for differentiating between benign phyllodes and fibroadenoma-however, the presence of a cystic component and strong lobulation favors the diagnosis of phyllodes tumor rather than fibroadenoma- as well as sharp delineation between the three subtypes of phyllodes tumors where imaging may be suggestive but not diagnostic of grading (8-12).

Pathologically, most phyllodes tumors show increased cellularity with increased stroma cells around ductal epithelium. FNAC is not sufficient to differentiate it from fibroadenoma. Core needle biopsy may be - but not always- 
able to reach a diagnosis guided by the degree of cellularity as well as increased stromal mitotic activity and nuclear atypia. According to mitotic frequency, nature of margins, stromal growth, cellularity and atypia, phyllodes tumors are subdivided pathologically into three types; benign, borderline and malignant which composes about $20-50 \%$ of all phyllodes tumors. Malignant phyllodes tumors tend to spread via hematological route mainly to the lung then bone. Phyllodes tumors - even benign type- tend to recur even after complete excision with higher tendency for malignant cases. Recurrent tumors may present with a higher grade than the primary ones $(2,4,13,14)$.

Wide local excision is the standard of care for benign, borderline and non-metastatic malignant phyllodes tumors - with or without adjuvant radiotherapy in malignant lesions with no proved value for chemotherapy or hormonal therapy. Axillary dissection is not recommended. Metastatic phyllodes tumor patients are candidate for palliative therapy with overall poor prognosis $(3,4,8,12,15)$.

\section{Authors' Contributions}

Omar Hamdy: conceptualization, data collection, writing \& revision. Gehad A Saleh: Data collection, writing. Sara Raafat: Data collection, writing. Abdelhadi M Shebl: Data validation, revision. Adel Denewer: operative part, supervision.

Conflict of interest: None declared.

\section{References}

1. Karihtala P, Rissanen T, Tuominen H. Male Malignant Phyllodes Breast Tumor After Prophylactic Breast Radiotherapy and Bicalutamide Treatment: A Case Report. Anticancer Res. International Institute of Anticancer Research; 2016;36(7):3433-6.

2. Kim JG, Kim SY, Jung HY, Lee DY, Lee JE. Extremely rare borderline phyllodes tumor in the male breast: a case report. Clin Imaging. Elsevier; 2015;39(6):1108-11.

3. Chougule A, Bal A, Rastogi P, Das A. Recurrent phyllodes tumor in the male breast in a background of gynaecomastia. Breast Dis. IOS Press; 2015;35(2):139-42.

4. Campagnaro EL, Woodside KJ, Xiao S-Y, Daller JA, Evers BM. Cystosarcoma phyllodes (phyllodes tumor) of the male breast. Surgery. Elsevier; 2003;133(6):689-91.

5. Konstantakos AK, Graham DJ. Cystosarcoma phyllodes tumors in men. Am Surg. United States; 2003 Sep;69(9):808-11.

6. Ansah-Boateng $\mathrm{Y}$, Tavassoli FA. Fibroadenoma and cystosarcoma phyllodes of the male breast. Mod Pathol an Off J United States Can Acad Pathol Inc. 1992;5(2):114-6.

7. Reingold IM, Ascher GS. Cystosarcoma phyllodes in a man with gynecomastia. Am J Clin Pathol. Oxford University Press Oxford, UK; 1970;53(6):852-6.

8. Ganesh V, Drost L, Lee J, Wan BA, Zhang L, Rakovitch E, et al. A retrospective review of phyllodes tumours of the breast: A single institution experience. The Breast. Elsevier; 2018;38:52-7.

9. Kamitani T, Matsuo Y, Yabuuchi H, Fujita N, Nagao M, Kawanami S, et al. Differentiation between benign phyllodes tumors and fibroadenomas of the breast on MR imaging. Eur J Radiol. Elsevier; 2014;83(8):1344-9.

10. Plaza MJ, Swintelski C, Yaziji H, Torres-Salichs M, Esserman LE. Phyllodes tumor: review of key imaging characteristics. Breast Dis. IOS Press; 2015;35(2):79-86.

11. McCarthy E, Kavanagh J, O'Donoghue Y, McCormack E, D'Arcy C, O'Keeffe SA. Phyllodes tumours of the breast: radiological presentation, management and follow-up. Br J Radiol. The British Institute of Radiology.; 2014;87(1044):20140239.

12. Strode M, Khoury T, Mangieri C, Takabe K. Update on the diagnosis and management of malignant phyllodes tumors of the breast. The Breast. Elsevier; 2017;33:91-6.

13. Idowu MO, Singh JA, Grimes MM. Overview of Pathology Evaluation of Breast Lesions and Quality Assurance BT - Diagnosis and Management of Breast Tumors: A Practical Handbook and Multidisciplinary Approach. In: Idowu MO, Shah PA, Hackney MH, Grimes MM, Geyer Charles Edward J, Arthur DW, et al., editors. Cham: Springer International Publishing; 2018. p. 35-72.

14. Efared B. Phyllodes tumors of the breast: clinicopathological analysis of 106 cases from a single institution. Breast Dis. IOS Press; 2018;(Preprint):1-7.

15. Kim J-Y, Yu JH, Nam SJ, Kim SW, Lee SK, Park W-Y, et al. Genetic and clinical characteristics of phyllodes tumors of the breast. Transl Oncol. Elsevier; 2018;11(1):18-23. 